\title{
Evaluation of The Impact Of Manual Tasks On Workers In An Oil Servicing Company
}

\author{
A. Kolawole ${ }^{1}$ and W.A. Buari ${ }^{2}$ \\ ${ }^{1,2}$ Department of Industrial and Production Engineering, \\ Faculty of Technology, University of Ibadan, Nigeria.
}

\begin{abstract}
Manual task activities have been found to contribute to a number of musculoskeletal disorders such as sprain and strain of the muscles and low back pain among others. This study examined the impact of manual tasks on workers in an oil and gas company in Nigeria. Twenty six manual task workers participated in the study and their physiological responses during work were evaluated through heart beat rate per minute and volume of oxygen consumption. Relative aerobic strain (RAS) for each of the 26 subjects was calculated through the volume of oxygen consumption as RAS ${ }_{1}$ and through the heart beat rate per minute as $\mathrm{RAS}_{2}$. The results showed that based on $\mathrm{RAS}_{1}$ and $\mathrm{RAS}_{2,} 8$ or $30.77 \%$ and 9 or $34.62 \%$ out of the 26 workers have the impact of the job within their capacity respectively while 18 or $69.23 \%$ and 17 (65.38\%) have the task beyond their capability based on $\mathrm{RAS}_{1}$ and $\mathrm{RAS}_{2}$ respectively. In order to ensure the safety and comfort of the workers, it may be necessary to assess the physical fitness of an intending manual task worker before employment
\end{abstract}

Keywords: - age correction factor $(A G)$, Heart beat rate, Manual task, Relative aerobic strain (RAS), Volume of Oxygen Consumption $\left(\mathrm{VO}_{2}\right)$

\section{INTRODUCTION}

Manual task refers to any activity or sequence of activities that requires a person to use his/her physical strength (musculoskeletal system) to perform work. Manual handling activities include the use of force in lifting, lowering, pushing, pulling, carrying, performing repetitive task; adopting awkward or sustained posture and using plant, tools or equipment that exposes workers to vibration [1]. [2] stated that although automation has significantly reduced the demand for human power in the modern industrial environment, muscular strength still remain an essential part of many occupations, particularly those involving manual materials handling or manual work. Manual tasks can lead to a number of musculoskeletal disorder including sprain and strain of muscles, injuries to muscle, ligaments, inter vertebral disc, and other structures in the back, injuries to soft tissues such as nerves, tendons in the wrists, arms and shoulders. It can also contribute negatively to the cardiovascular system, for as physical activity increases, muscle demands more oxygen and metabolites the body signals, this demand increases the heart beat rate. When the muscles demand for oxygen and metabolism cannot be met, it produces accumulation of toxic lactic acid which results to fatigue occurring during physical activities.

The lack of consideration of the effects of manual tasks on workers has led to a large percentage of the working population to be involved in the tasks that are beyond their physical capabilities [3;4]. This decreases productivity and increases possibility of operator-related health hazards. The negative impacts of manual tasks have been reported in many studies to have included among others musculoskeletal disorder and cardiovascular problems $[5 ; 6 ; 7 ; 8]$. These symptoms are highlights of many workstations in many industrially developing countries. [9] noted that common features of industries in developing countries are improper workplace design, ill-structured jobs, mismatch between worker abilities and job demands, adverse environments, poor humanmachine system design and inappropriate management programmes. [10;11] commented that it is good to ensure that workers' capabilities match the kind of work they do which may lead to higher productivity, safety of the workers and reduction in rate of accidents.

As activities of ergonomists are becoming more in Nigeria, research works are being conducted in order to solve workplace problems that are associated with manual tasks; e.g. [12] and [13]. However the case of oil and gas industry in Nigeria seems not to have been explored sufficiently perhaps due to high level of automation in the sector. Hence, in this study, we examined the impacts of manual tasks on workers working in a typical oil servicing company in Nigeria with focus on the physical capabilities of the workers and energy expended during work. The findings may be useful to make appropriate decisions as regards the task to be assigned to workers at the lower cadre in oil servicing establishments and also create the appropriate work environment for the workers to ease their jobs. 


\section{METHODOLOGY}

This study was conducted in a multinational oil servicing company located in one of the cities in the south-south geo-political zone of Nigeria. Manual activities in the establishment include lifting equipment from delivery van and lifting of equipment from either the store or the reception area to the workshop. Twenty six (26) workers ( 22 men and 4 women) participated in the study. The male workers have experience of 2 to 20 years, while the female workers have between 2 to 7 years on the job experience. One can reasonably assume that the workers are well used to the task. The following data were obtained from the subjects after the purpose of study has been thoroughly explained to them and they all gave their consents; age in years, heart beat rate per minute at rest and while working, volume of oxygen consumption while working $\left(\mathrm{VO}_{2 \mathrm{w}}\right)$. The heart beat rate per minute for each worker was measured as described by [13]. Measurement of heart beat rate per minute while at rest $\left(\mathrm{HR}_{\mathrm{r}}\right)$ and when working $\left(\mathrm{HR}_{\mathrm{w}}\right)$ were taken three times for each worker and the mean value for each were recorded as the heart beat rate per minute while at rest and while working respectively. The $\mathrm{VO}_{2 \mathrm{w}}$ consumed while working was determined using Incentive Spiro meter (Airlife ${ }^{\mathrm{TM}}$ ) which usually measures the amount of air breathe in. The actual oxygen expended during work was obtained by calculating $21 \%$ of the amount of air breathe in. The summary of the data collected are shown in Table 1.

Table 1: Subjects' heart beat rate at rest and at work and volume of oxygen consumption at work

\begin{tabular}{|c|c|c|c|c|c|c|c|c|c|c|c|}
\hline \multirow[t]{2}{*}{ Subject } & \multirow[t]{2}{*}{ Sex } & \multirow[t]{2}{*}{ Age(years) } & \multicolumn{3}{|c|}{$\begin{array}{l}\text { Heart beat rate per } \\
\text { minute at rest }\end{array}$} & \multirow{2}{*}{$\begin{array}{l}\begin{array}{l}\text { Mean of } \\
\text { heart beat } \\
\text { rate at rest }\end{array} \\
\mathrm{HR}_{\mathrm{R}}\end{array}$} & \multicolumn{3}{|c|}{$\begin{array}{l}\text { Heart beat rate } \\
\text { per minute at } \\
\text { work }\end{array}$} & \multirow{2}{*}{$\begin{array}{l}\text { Mean of heart } \\
\text { beat rate at } \\
\text { work } \\
\mathrm{HR}_{w} \\
\end{array}$} & \multirow{2}{*}{$\begin{array}{c}\text { Vol. of } \mathrm{O}_{2} \text { at } \\
\text { work } \text { Lmin }^{-1} \\
\mathrm{VO}_{2 \mathrm{w}}\end{array}$} \\
\hline & & & 1 & 2 & 3 & & 1 & 2 & 3 & & \\
\hline 1 & $M$ & 51 & 80 & 81 & 83 & 81 & 127 & 130 & 131 & 129 & 2.47 \\
\hline 2 & $M$ & 45 & 84 & 87 & 88 & 86 & 120 & 123 & 121 & 121 & 2.308 \\
\hline 3 & $M$ & 48 & 76 & 77 & 76 & 76 & 118 & 119 & 118 & 118 & 2.215 \\
\hline 4 & $M$ & 39 & 75 & 70 & 72 & 72 & 101 & 105 & 103 & 103 & 1.89 \\
\hline 5 & $M$ & 27 & 60 & 63 & 61 & 61 & 110 & 112 & 112 & 111 & 2.052 \\
\hline 6 & $M$ & 44 & 70 & 70 & 71 & 70 & 105 & 102 & 103 & 103 & 1.82 \\
\hline 7 & $M$ & 27 & 74 & 74 & 74 & 74 & 128 & 130 & 133 & 130 & 2.47 \\
\hline 8 & $M$ & 20 & 59 & 59 & 60 & 59 & 140 & 139 & 140 & 140 & 2.679 \\
\hline 9 & $M$ & 27 & 72 & 74 & 74 & 73 & 132 & 128 & 129 & 130 & 2.424 \\
\hline 10 & $M$ & 42 & 80 & 83 & 85 & 83 & 88 & 90 & 93 & 90 & 1.541 \\
\hline 11 & $M$ & 23 & 60 & 60 & 59 & 60 & 111 & 107 & 106 & 108 & 1.936 \\
\hline 12 & $M$ & 28 & 70 & 70 & 69 & 70 & 100 & 102 & 104 & 102 & 1.82 \\
\hline 13 & $M$ & 34 & 79 & 76 & 75 & 77 & 101 & 103 & 103 & 102 & 1.843 \\
\hline 14 & $M$ & 23 & 66 & 72 & 68 & 69 & 122 & 120 & 118 & 120 & 2.238 \\
\hline 15 & $M$ & 35 & 80 & 84 & 80 & 81 & 148 & 145 & 140 & 144 & 2.819 \\
\hline 16 & $\mathrm{~F}$ & 26 & 66 & 67 & 69 & 67 & 99 & 101 & 100 & 100 & 1.797 \\
\hline 17 & $M$ & 28 & 74 & 70 & 71 & 72 & 128 & 128 & 129 & 128 & 2.424 \\
\hline 18 & $M$ & 61 & 81 & 81 & 82 & 81 & 142 & 140 & 141 & 141 & 2.702 \\
\hline 19 & $M$ & 41 & 75 & 70 & 72 & 72 & 134 & 136 & 138 & 136 & 2.61 \\
\hline 20 & $M$ & 35 & 79 & 81 & 81 & 80 & 119 & 121 & 121 & 120 & 2.261 \\
\hline 21 & $M$ & 21 & 56 & 60 & 62 & 59 & 105 & 103 & 100 & 103 & 1.843 \\
\hline 22 & $M$ & 26 & 80 & 78 & 76 & 78 & 131 & 138 & 133 & 134 & 2.656 \\
\hline 23 & $M$ & 34 & 76 & 78 & 76 & 77 & 128 & 131 & 130 & 130 & 2.493 \\
\hline 24 & $\mathrm{~F}$ & 27 & 52 & 55 & 56 & 54 & 91 & 90 & 91 & 91 & 1.541 \\
\hline 25 & $\mathrm{~F}$ & 31 & 61 & 61 & 63 & 62 & 110 & 112 & 114 & 112 & 2.052 \\
\hline 26 & $\mathrm{~F}$ & 25 & 56 & 54 & 53 & 54 & 87 & 87 & 88 & 87 & 1.471 \\
\hline Mean & & 33.38 & & & & 71.08 & & & & 116.65 & 2.17 \\
\hline $\begin{array}{l}\text { Standard } \\
\text { Deviation }\end{array}$ & & 10.31 & & & & 9.17 & & & & 16.8 & 0.39 \\
\hline
\end{tabular}

The maximum volume of Oxygen consumption $\left(\mathrm{VO}_{2 \max }\right)$ which is a measure of a worker's maximum capacity was determined by using Astrand - Astrand nomogram as in [14] shown in equations 1 and 2 for men and women respectively:

For men: $\mathrm{VO}_{2 \max }=\mathrm{AG}\left(131.5 \mathrm{VO}_{2 \mathrm{w}}\right) \div\left(\mathrm{HR}_{\mathrm{w}}-62\right)$

For women: $\mathrm{VO}_{2 \max }=\mathrm{AG}\left(131.5 \mathrm{VO}_{2 \mathrm{w}}\right) \div\left(\mathrm{HR}_{\mathrm{w}}-72\right)$

Where ' $\mathrm{AG}$ ' is age correction factor given by [14] in equation 3 below:

$\mathrm{AG}=1.12-(0.0073)$ age

And $\mathrm{HR}_{\mathrm{w}}$ is heart beat rate per minute while working 
To determine the impact of any manual task on any worker, the relative aerobic strain (RAS) of such worker while performing the task may be calculated and then compared with the recommended relative aerobic strain (RAS). The RAS is defined as the fraction (expressed as a percentage) of a worker's oxygen consumption measured on the job relative to his or her $\mathrm{VO}_{2 \max }$ measured in the laboratory [14], and it is one of the ways of assessing a worker's response to manual tasks and the demand of such task on his/her capacity. This can be used to determine the physical fitness of workers. An approximate value of RAS can be got by calculating percentage heart rate range (\% HR range) with the Karnoven formula if only the heart beat rate data is available [15]. In this study, $\mathrm{RAS}_{1}$ is the Relative Aerobic Strain calculated from volume of Oxygen consumption while RAS 2 is the Relative Aerobic Strain obtained from heart beat rate per minute.

$$
\begin{aligned}
& R A S_{1}=\left(\frac{V O_{2 w}}{V O_{2 \max }}\right) \times 100 \\
& R A S_{2}=\left\{\left(H R_{w}-H R_{r}\right) /\left(H R_{\max }-H R_{r}\right)\right\} \times 100 \\
& H R_{\max }=220-A g e
\end{aligned}
$$

Where:

$\mathrm{VO}_{2 \mathrm{w}}$ is volume of oxygen consumed by a worker while working

$\mathrm{VO}_{2 \max }$ is the maximum volume of oxygen consumption possible by a worker

$\mathrm{HR}_{\mathrm{r}}$ is the heart beat rate per minute for a worker while at rest

$\mathrm{HR}_{\mathrm{w}}$ is the heart beat rate per minute for a worker while working

$\mathrm{HR}_{\max }$ is the maximum heart beat rate per minute possible for a worker

Age is in years.

\section{DATA ANALYSIS AND DISCUSSIONS OF RESULTS}

\subsection{DATA ANALYSIS}

From the result obtained in Table1 the age of the workers was between 20 and 61 years with mean age as 33.38 years and standard deviation of 10.31

Using equations 1,2 and $3, \mathrm{VO}_{2 \max }$ can be calculated:

E.g., from equation 1, for a male worker; $\mathrm{VO}_{2 \max }=\left[\mathrm{AG}\left(131.5 \mathrm{VO}_{2 \mathrm{w}}\right) \div\left(\mathrm{HR}_{\mathrm{w}}-62\right)\right]$

For subject 1 from Table 1; age= 51years; $\mathrm{AG}=1.12-(0.0073)$ age

$$
\mathrm{AG}=1.12-(0.0073) 51=0.7477
$$

Substituting this value of $\mathrm{AG}$ into equation of $\mathrm{VO}_{2 \max }$ above:

$$
\left.\mathrm{VO}_{2 \max }=[0.7477(131.5)(2.47)] \div(129-62)\right]
$$

$\mathrm{VO}_{2 \max }=3.625$ litmin $^{-1}$

Hence maximum volume of oxygen consumption $\left(\mathrm{VO}_{2 \max }\right)$ possible for subject 1 is $=3.625$ litmin $^{-1}$

To obtain $\mathrm{RAS}_{1}$ for subject 1 , from equation 4 above and with $\mathrm{VO}_{2 \mathrm{w}}=2.47$;

$\operatorname{RAS}_{1}=(2.47 / 3.625) \times 100$

$\mathrm{RAS}_{1}=68.14 \%$

$\mathrm{RAS}_{1}$ for subject $1=68.14 \%$

Similar procedure was followed to obtain $\mathrm{VO}_{2 \max }$ and $\mathrm{RAS}_{1}$ for other subjects and the results are shown in column 6 and 7 respectively of Table 2 .

To determine $\mathrm{RAS}_{2}$ i.e. relative aerobic strain through the heart beat rate per minute, using equations 5 and 6 ; For subject 1 , age $=51$ years, Heart beat rate per minute while at rest $\mathrm{HR}_{\mathrm{r}}=81$, while heart beat rate per minute while working $\mathrm{HR}_{\mathrm{w}}=129$, substituting these values into appropriate equations 5 and 6 :

$\mathrm{HR}_{\max }=220$ - (age) years

$\mathrm{HR}_{\max }=220-51=169$

$R A S_{2}=\left\{\left(H R_{w}-H R_{r}\right) /\left(H R_{\max }-H R_{r}\right)\right\} \times 100$

$R A S_{2}=[(129-81) /(169-81)]=48 / 88=54.55 \%$

In a similar way, $\mathrm{RAS}_{2}$ for other subjects can be determined and is as shown in column 8 of Table 2 . 
Table 2: Subjects' Relative aerobic strain from oxygen consumption $\left(\operatorname{RAS}_{1}\right)$ and Relative aerobic strain from heart beat rate $\left(\mathrm{RAS}_{2}\right)$

\begin{tabular}{|c|c|c|c|c|c|c|c|}
\hline Subject & Sex & Age in years & $\mathbf{H R}_{\max }=(\mathbf{2 2 0}$-age) & $\mathrm{HR}_{\mathbf{x}}$ & VO $_{\text {max }}$ & RAS $_{\mathbf{1}}$ (\%) & RAS $_{\mathbf{2}}$ (\%) \\
\hline 1 & $\mathrm{M}$ & 51 & 169 & 129 & 3.625 & 68.14 & 54.55 \\
\hline 2 & $\mathrm{M}$ & 45 & 175 & 121 & 4.071 & 56.69 & 39.33 \\
\hline 3 & $\mathrm{M}$ & 48 & 172 & 118 & 4.002 & 55.35 & 43.75 \\
\hline 4 & $\mathrm{M}$ & 39 & 181 & 103 & 5.062 & 37.34 & 28.44 \\
\hline 5 & $\mathrm{M}$ & 27 & 193 & 111 & 5.083 & 40.37 & 37.88 \\
\hline 6 & $\mathrm{M}$ & 44 & 176 & 103 & 4.662 & 39.04 & 31.13 \\
\hline 7 & $\mathrm{M}$ & 27 & 193 & 130 & 4.409 & 56.02 & 47.06 \\
\hline 8 & $\mathrm{M}$ & 20 & 200 & 140 & 4.399 & 60.9 & 57.45 \\
\hline 9 & $\mathrm{M}$ & 27 & 193 & 130 & 4.326 & 56.03 & 47.5 \\
\hline 10 & $\mathrm{M}$ & 42 & 178 & 90 & 5.887 & 26.18 & 7.37 \\
\hline 11 & $\mathrm{M}$ & 23 & 197 & 108 & 5.269 & 36.74 & 35.04 \\
\hline 12 & $\mathrm{M}$ & 28 & 192 & 102 & 5.478 & 33.22 & 26.23 \\
\hline 13 & $\mathrm{M}$ & 34 & 186 & 102 & 5.282 & 34.89 & 22.94 \\
\hline 14 & $\mathrm{M}$ & 23 & 197 & 120 & 4.831 & 46.33 & 39.84 \\
\hline 15 & $\mathrm{M}$ & 35 & 185 & 144 & 3.908 & 72.13 & 60.58 \\
\hline 16 & $\mathrm{~F}$ & 26 & 194 & 100 & 7.849 & 22.89 & 25.98 \\
\hline 17 & $\mathrm{M}$ & 28 & 192 & 128 & 4.421 & 54.83 & 46.67 \\
\hline 18 & $\mathrm{M}$ & 61 & 159 & 141 & 3.035 & 89.03 & 76.92 \\
\hline 19 & $\mathrm{M}$ & 41 & 179 & 136 & 3.806 & 68.58 & 59.81 \\
\hline 20 & $\mathrm{M}$ & 35 & 185 & 120 & 4.432 & 51.02 & 38.1 \\
\hline 21 & $\mathrm{M}$ & 21 & 199 & 103 & 5.714 & 32.25 & 31.43 \\
\hline 22 & $\mathrm{M}$ & 26 & 194 & 134 & 4.512 & 58.87 & 48.28 \\
\hline 23 & $\mathrm{M}$ & 34 & 186 & 130 & 4.204 & 59.3 & 48.62 \\
\hline 24 & $\mathrm{~F}$ & 27 & 193 & 91 & 9.844 & 15.65 & 26.62 \\
\hline 25 & $\mathrm{~F}$ & 31 & 189 & 112 & 6.029 & 34.04 & 39.37 \\
\hline 26 & $\mathrm{~F}$ & 25 & 195 & 87 & 12.094 & 12.16 & 23.4 \\
\hline Mean & & 33.38 & 186.62 & 116.65 & 5.24 & 46.85 & 40.17 \\
\hline Std Dev & & 10.31 & 10.31 & 16.81 & 1.96 & 18.37 & 14.86 \\
\hline
\end{tabular}

Key:

$\mathrm{HR}_{\max }$ - maximum heart beat rate per minute possible for a worker

$\mathrm{RAS}_{1}$ - the Relative Aerobic Strain from volume of Oxygen consumption

$\mathrm{RAS}_{2}$ - the Relative Aerobic Strain from heart beat rate per minute.

$\mathrm{VO}_{2 \max }$ is the maximum volume of oxygen consumption possible by a worker

\subsection{DISCUSSIONS OF RESULTS}

From the results, the average heart beat rate per minute at rest $\left(\mathrm{HR}_{\mathrm{r}}\right)$ and while working $\left(\mathrm{HR}_{\mathrm{w}}\right)$ for all the subjects are 71.08 and 116.65 respectively and average volume of oxygen consumption at work is $2.17 \mathrm{Lmin}^{-}$ ${ }^{1}$. The mean relative aerobic strain $\left(\mathrm{RAS}_{1}\right)$ calculated from oxygen consumption is $46.85 \%$ while relative aerobic strain $\left(\mathrm{RAS}_{2}\right)$ obtained from heart beat rate is $40.17 \%$. A worker's response to impact of work can be got from his heart beat rate or oxygen consumption. [12] reported that a more physically fit employee would have his heart beat rate per minute increase less rapidly than his/her counterpart who is less fit while subjected to the same workload. The higher the heart beat rate/oxygen consumption, the more impact the task is on the individual or more difficult is the job on the worker.

The relative aerobic strain is one of the ways to ascertain the demand of task on the capacity of a worker. Several authors have suggested a safe value of RAS for manual task workers. [16] had recommended that RAS should not exceed $50 \%$ for an eight hour work day job but $25-55 \%$ for construction workers. Latter, [17] recommended 30-35\% for all day job. If 35\% RAS is used as the safe value, then the impact of the task is too severe on workers whose RAS values are greater than $35 \%$. In order words, the workers may not be able to sustain the job without putting their health and comfort at risk if they are to be performing the task on daily basis.

From Table 2, $\mathrm{RAS}_{1}$ (relative aerobic strain calculated from oxygen consumption) for 8 workers are $35 \%$ or below i.e. only $30.77 \%$ of subjects in the study would be able to do the job without being at risk while 18 or $69.23 \%$ would find the job to be beyond their physical capability. Result of relative aerobic strain from the heart beat rate $\left(\mathrm{RAS}_{2}\right)$ indicates that 9 workers have their $\mathrm{RAS}_{2}$ less than $35 \%$ i.e. $34.62 \%$ of the workers have the job within their physical capability but 17 or $65.38 \%$ would have the job to be too stressful thereby putting their safety at risk. These observations are summarized in Table 3. 
Table 3: Number of workers that task is safe and unsafe for based on (RAS) value of $35 \%$

\begin{tabular}{|c|c|c|}
\hline $\begin{array}{l}\text { Relative aerobic } \\
\text { Strain (RAS) }\end{array}$ & $\begin{array}{l}\text { No of workers that task is safe (RAS } \\
\text { < 35\%) }\end{array}$ & $\begin{array}{l}\text { No of workers that task is not safe } \\
\text { (RAS > 35\%) }\end{array}$ \\
\hline RAS $_{1}$ & $8(30.77 \%)$ & $18(69.23 \%)$ \\
\hline $\mathrm{RAS}_{2}$ & $9(34.62 \%)$ & $17(65.38 \%)$ \\
\hline
\end{tabular}

The results as displayed in Fig.1 fairly agree with previous findings $[18 ; 19 ; 20]$ that the heart beat rate and oxygen consumption rate have direct relationship.

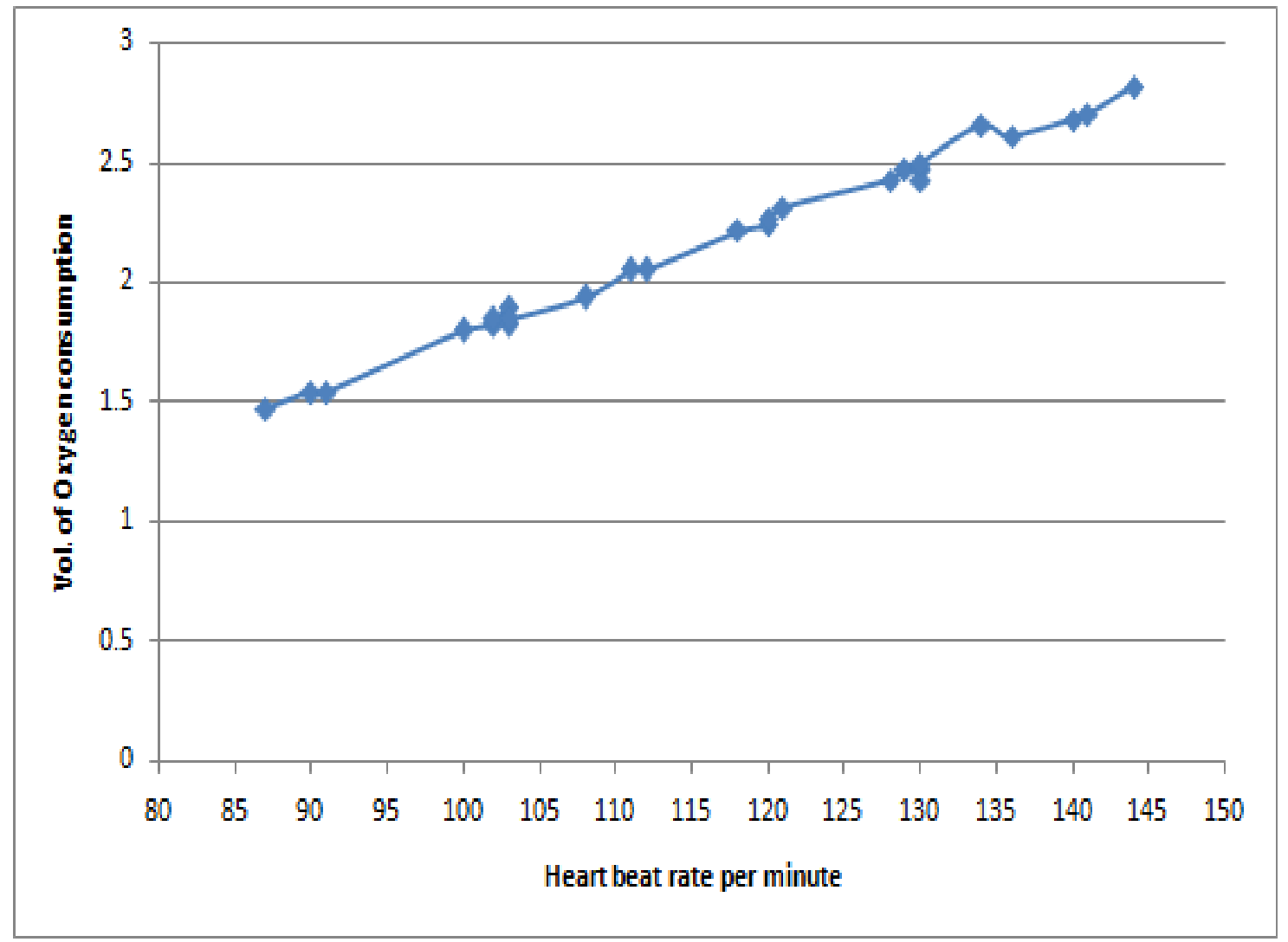

figure 1: Relationship between heart beat rate per minute and oxygen consumption rate

Furthermore, the implication of these results is that if the ergonomics principles that consider the safety, comfort and well being of employees while performing their jobs are anything to go by, then, 18 workers are not supposed to be doing the manual task that was studied based on the criterion of RAS $_{1}$ and 17 are not if the $\mathrm{RAS}_{2}$ is the basis for determining those that the impact of the task is excessive for thereby making them to be prone to occupational hazards and the likely negative effects of musculoskeletal disorder. It appears thorough investigation of the workplace and environment is needed in order to possibly reduce the workload on the workers.

\section{CONCLUSIONS AND RECOMMENDATIONS}

In this study, the impact of manual tasks on workers in an oil servicing company was examined using relative aerobic strain as the criterion. The results obtained showed that the impact of the task is rather much on almost 18 of the 26 workers that participated in the study. About 8 of the workers would however be able to perform the job as it appears they have the capacity to cope with the job. Linear relationship seems to exist between the heart beat rate per minute and the volume of oxygen consumption per minute while working. In view of the outcomes of this study, It is suggested that there is need to redesign the work content of the job in order to make the work environments more conducive for the workers thereby reducing the chance of occupational hazards. Also, prior to employing a manual tasks worker, his physical fitness should be assessed to determine whether he has the capacity to do the job. Only a fit worker should be employed for a job for which he has the capacity to perform in order to ensure safety and comfort of the worker which may lead to higher productivity while at work. 


\section{REFERENCE}

[1] Code of Practice Manual Task 2010: Commission for Occupational Safety and Health, Department of Commerce, Government of Western Australia. Available online http://www.commerce.wa.gov.au/worksafe/pdf/codes of Practice/Code manual handling.pdf

[2] A. Freivalds and B. W. Niebel, Niebel's methods, standards and work design (McGraw-Hill Higher Education, 2009).

[3] J. Sluiter and Frings-Dresen, What do we know about ageing at work? Evidence based fitness for duty and health in fire fighters, Ergonomics, Vol 50, No.11, 2007. pp. 1897-1913.

[4] M. K. Chung, L. J. Yue, L. Inseok, and I. C. Kyung, Physiological workload evaluation of carrying soft drink beverage boxes on the back: Applied Ergonomics 36, 2005, pg 569-574

[5] A. Klussmann, U. Steinberg, F. Liebers, H. Gerbhardt and A. Rieger, The key indicator method for manual handling operations (KIM-MHO) - evaluation of a new method for the assessment of working conditions within a cross-sectional study. BMC Musculoskeletal Disorders 11:272, 2010

[6] O. G. Akanbi and A. N. Ikemefuna, Tailor's chair and musculoskeletal disorders in Nigeria Ergonomics $S A$, (2) 2010.

[7] A. Shukor, An assessment of occupational hazards and ergonomics risk factors on young male workers in Malaysia. Injury Prevention Journal Abstract, 2010

[8] P. Parimalam, N.Kamalamma and A. K. Ganguli,: Ergonomic interventions to improve work environment in garment manufacturing units, Indian Journal of Occupational and Environmental Medicine Volume 10 - Issue 2, 2006

[9] A. A. Shikdar, N. M. Sawaqed, Worker productivity, and occupational health and safety issues in selected industries. Computer and Industrial Engineering 45, 2003 pp 563-572

[10] P. A. Scott, and C. J. Christie, An indirect method to assess the energy expenditure of manual labourers in situ. South Africa Journal of Science, 100, 2004, $694-698$.

[11] A. Samanta, and B. B. Chartterjee, A physiological study of manual lifting of loads in India. Ergonomics, 24 (7), 1981, pp $557-564$.

[12] A. Kolawole, and O.P. Kehinde, Physiological Evaluation of physical fitness of manual task workers - A case study of a manufacturing firm. Nigerian Journal of Engineering Research and Development (NJERD).Vol.6 No.2, 2007 Pp $27-32$.

[13] S. O. Ismaila, K. T. Oriolowo, and O. G. Akanbi Work capacity of assessment of Nigerian bricklayers. Management Science Letters (2) pp2634-272

[14] F. Tayyari, and J. Smith, Occupational ergonomics principles and applications. (Kluwer Academic publishers: Massachusetts, 2003)

[15] V. Louhevaara, J, Smolander, T, Aminoff and J. Ilmarinen, Assessing physical workload ", Karwowski W and Salvendy G (Ed.), Ergonomics in Manufacturing, (Engineering and Management Press, a division of the Institute of Industrial Engineer Norcross Georgia 1998).

[16] P. O. Astrand, and K. Rodahl, Textbook of work physiology: physiology bases of exercise $3^{\text {rd }}$ edition.(McGraw-Hill, New York 1986)

[17] J. Ruternfranz, J. Ilmarinen, F.Klimmer, and H. Kylian, Work Load and Demanded Physical Performance Capacity Under Different Industrial Working Condition" Fitness for Aged, Disabled, and Industrial Worker in M. Kaneko (ed.) International Series on Sport Sciences, Vol 20 (Champaign, Il: Human Kinetics Books, 1990) 